JNE 5 (1) (2019)
Journal of Nonformal Education
UNttp://journal.unnes.ac.id/nju/index.php/jne

\title{
Learning Management of Nonformal Education Units in Sanggar Kegiatan Belajar
}

\author{
Muhammad Anis Sufyan ${ }^{凶}$, Komsun Nurhalim, Imam Shofwan \\ Department of Nonformal Education, Postgraduate, Universitas Negeri Semarang, Indonesia
}

DOI: http://doi.org/10.15294/jne.v5i1.18335

\section{Info Artikel}

\section{History Articles:}

Accepted, 09 January 2019

Approved, 15 January 2019

Published Februari 2019

\section{Keywords:}

learning management, nonformal education

\begin{abstract}
Abstrack
Learning in the Semarang Nonformal Education Unit Sanggar Kegiatan Belajar (SKB) equality education especially the package $C$ program focuses more on students or learning citizens, namely the occurrence of the learning process. The diversity of the backgrounds of the learning community makes participation in the learning process and the learning outcomes of each learning citizen more varied. In the learning process the learning climate created by tutors is more centered on learning centers. The purpose of this study is to describe and analyze Package C learning. This study uses a qualitative approach. Data collection techniques are carried out by observation, interviews, and documentation. Data analysis techniques include data collection, data reduction, data presentation and conclusion drawing. Check the validity of the data using source triangulation and methods. The results of the study show that the learning plan of the Package $C$ Program includes: formulating learning objectives, teaching materials, methods, learning resources and establishing assessment of learning outcomes. Implementation involves three steps, namely introduction, core and closing. The learning evaluation that is apllied is summative and formative evaluation.
\end{abstract}

(C) 2019 Universitas Negeri Semarang

\begin{tabular}{lr}
\hline Correspondence address: & p-ISSN 2442-532X \\
Department of Nonformal Education, Universitas Negeri Semarang & e-ISSN 2528-4541 \\
Sekaran Raya Campus-Gunungpati Semarang, Building A2. 2 ${ }^{\text {nd }}$ Floor &
\end{tabular}

E-mail: pls213078@gmail.com 


\section{INTRODUCTION}

Education is one of the important elements in national development since it is an investment in developing human resources. he role of education will affect human resources in quality and quantity, so that it can improve the welfare and prosperity of the people in a country. (Shofwan, 2014: 50). Improving the quality of human resources is strongly determined by the education received by the individuals so that it functions as a encouragement in enhancing human skills and abilities to become a quality society. It is supported by the results of a study from Widodo (2016) stating that to alleviate human resources problems in Indonesia, the transformation of education is a necessity since with this, human education in Indonesian can be fully implemented.

As explained in Law Number 20 year 2003 about National Education System, it is stated that: "Education is a conscious and planned effort to make a learning atmosphere and learning process so that students can actively develop their potential to have religious spiritual power, self-control, personality, intelligence, noble character, and skills needed by themselves, society, nation and state". The future of a nation is very dependent on community which is a product of quality education since education is seen as a tool which is capable of produce intellectuals. A nation that puts aside or considers education as an unimportant thing is the same as killing the future hopes. Along with the dynamics of the development of education which is increasingly move forward, the current education system in Indonesia need to be reconsidered.

According to Sungsri (2018) stated that education is a continuous process throughout lifetime. Suhaenah (2016) emphasized that the function of education must be truly concerned in order to achieve the objectives of national education since its purpose is to serve as a clear direction toward education activities so that it must be directed to (1) education is implemented in a democratic and equitable manner and is not discriminatory with upholding human rights, religious values, cultural values, and national pluralism, (2) education is implemented as a systemic unity with an open and multi-meaningful system, (3) education is implemented as a process of civilizing and empowering students that lasts a lifetime, (4) education is implemented by giving exemplary, developing willingness, and developing students' creativity in the learning process, (5) education is implemented by developing a culture of reading, writing, and counting for all people, (6) education is carried out by empowering all components of society through participation in implementing and controlling quality of education services.

In Law Number 20 year 2003 article 1 section 10 explains that the education unit is an education service group that organizes education on informal, formal, nonformal section and at every level and type of education. Nonformal education, according to Trisnamansyah (Kamil, 2012: 30) is a science which systematically studies socio-cultural interactions between learners as an object with learning resources in order to achieve educational purposes wanted by emphasizing the formation of independence in order to learn for lifetime. Whereas, according to Venze (2018) nonformal education is every educational activity that is organized, systematic, and carried out outside the formal system framework to provide certain types of learning for certain subgroups in the population, either adults or children.

Package C equivalency education program is one of equality programs carried out by nonformal education institutions. Learning in equality education of Nonformal Education Unit Sanggar Kegiatan Belajar Semarang City especially for package C program, it focuses more on students, namely the occurance of learning process. According to Rustaman (2001: 461) the learning process is a process in which there are interaction activities between teacher and students, and reciprocal communication that takes place in educational 
situations to achieve the learning purposes. Whereas according to Jogiyanto (2007: 12) he also argued that a learning can be defined as a process in which an activity comes or changes through the reaction of a situation faced and the characteristics from the changes in activity cannot be explained based on genuine reaction tendencies, maturity or temporary changes.

According to Raharjo (2005) a learning is a learning activity process that involves changes in cognitive, psychomotor, and affective aspects as a form of personal and social adjustment so that individuals are expected to be able to adapt to their environment and their learning necesity are fulfilled and bring optimal change. So that it can be concluded that learning is the process of interaction between learners and tutors and also learning resources in a learning environment that includes tutors and learners that exchange information one another. According to Sutarto (2016) the quality learning process very requires optimal support from various resources, including tutors' knowledge and attitudes as the main actor of learning, leadership from the organizer, the work climate created, and the existence of financial support and the availability of adequate learning infrastructure for sustainability learning process.

Learning cycle theory states that learning is acquired from the learning process of experiences gained in daily activities which are then concluded and become a concept and value systems that are applied for future success (Mustika, 2013). According to Illeris (2003), good learning is characterized by high student responses to the learning subject. Students seriously listen to or pay attention toward the teacher's explanation, are brave to ask questions to the teacher if there is an explanation from the teacher that is still unacceptable, are brave to answer questions from the teacher, do the assignments given by the teacher on time, and are brave to express opinions verbally. According to Slameto (2003: 54), learning success is influenced by two main factors. They are internal factors and external factors. While according to Suryabrata (1989) in the journal of (Aritonang, 2008), stated that the factors that influence learning outcomes are classified into three, they are: internal factors, external factors, and instrument factors.

Looking at the explanation above, this research will examine learning in Package $C$ Chase Program. The aims of this study were to describe and analyze (1) planning of Package $C$ learning (2) implemention of Package $C$ learning (3) Evaluation of Package $C$ learning.

\section{METHODS}

The approach used in this study was a qualitative approach. According to Bungin (2007: 68) social research using a qualitative descriptive format aims to describe, summarize various conditions, various situations, or various phenomena of social reality in society that become research object, and attempting to attract that reality to the surface as a characteristic, character, traits, models, signs, or descriptions of certain conditions, situations, or phenomena. By using qualitative descriptive method that describes the phenomena that exist, it will be obtained deep understanding of interpretation and reality about the meaning of reality and facts because the problems in this research are not in numbers but descricription, describe and explain the implementation of learning models and work readiness of participants after the training.

The determination of data sources of the interviwees in this qualitative research was conducted purposively. Purposive is that the samples (interviewees/informants) are chosen with certain considerations and objectives. Certain considerations made by the researcher were intended to determine and select the interviewees/informants who are considered knowing the most about the social situation studied. The key informants in this study were people who had strategic positions that understand about Package $\mathrm{C}$ learning, such as the Head of Nonformal Education Unit Sanggar Kegiatan Belajar, and its tutors. Through these key informants, they were able 
to give advices and supports for the access to other evidence sources that could support the research focus. Access to other sources of evidence can be obtained in the form of information from the learners.

The data source in this study was primary data which was data obtained from the Head of Nonformal Education Unit Sanggar Kegiatan Belajar, tutors and learners. Secondary data which was additional data used to complete data. Secondary data was obtained through documentation or literature by examining scientific books related to the Package C learning. Techniques for data collection used are observation, interviews and documentation.

The data validity used in this study was data/source triangulation and methods triangulation. The source triangulation used by the researcher was comparing and checking both the degree of trust in information obtained by using guidelines that had been prepared or prepared for data collection. The methods triangulation used were interview, observation, and documentation methods. The data analysis used in this study took place with the process of collecting data. The analysis consisted of three activity lines. They were data reduction, data presentation and withdrawal.

\section{RESULTS AND DISCUSSION}

\section{Package C Learning Plan}

The Learning plan of package $C$ program was systematic process in a decision making about the behavior that will be taken in the future to achieve the learning objectives related to the students' functional skill and entrepreneurship. It was called systematic because that planning was implemented by using certain priciples. These principles included decision-making process, scientific use of knowledge and technique, and organized anctions or activities (Hidayat, 2016). Based on the research results, the learning process plan of package $\mathrm{C}$ in Semarang Nonformal Education Unit Sanggar Kegiatan Belajar contained five main components which must be done on it.
They were (1) learning objectives, (2) teaching material, (3) teaching methods, (4) learning sources, and (5) learning outcomes assessment.

First, based on the results of the study, the package $\mathrm{C}$ learning objectives were the students could master the knowledge and gain the abilities, so the positive mindset changes occurred as provisions to compete the work world. This result was in line with the research conducted by Saputra (2015) which stated that learning objectives was to provide skills to the students and improve their potential with the certain skills as a means of life. The objective formlation process was formulated by those who have a role in arranging the package $\mathrm{C}$ program, it was organized based on the need identification results, while the students did not involve in formulating the learning objectives. The need identification process was carried out before the decision of the package $\mathrm{C}$ program implementation. It was done by the tutor in whom the result would be created as guidance in implementing a program. So, it was formed a module and learning media as the output of need identification activity.

This research result was supported by the study of Syahid (2017) which stated that the indication of package $C$ program aimed to identify the learning plan, learning process, learning times, facilities, tools, and learning media that were needed to support the success of the learning process. In line with the research conducted by Auliya (2016), it showed that the result of the learning strategy used was adapted with the condition and the needs of the students, those were relaxed and humorous learning. Those strategies caused a sense of comfort and interest of the students themselves, so it directed them in achieving their learning goals.

Second, the material taught in Semarang Nonformal Education Unit Sanggar Kegiatan Belajar was the same as formal school subject which consisted of several subjects and additional subjects in the form of skills. Those skills subjects included sewing, computers, and cosmetology. 
Third, according to Rifa'i (2009), learning method was the way of presenting the subject matter conducted by the teachers so the learning process was occurred in the students themselves to achieve their goals. The use of the learning method applied by Nonformal Education Unit Sanggar Kegiatan Belajar in Semarang was more towards the conventional learning. That method included lectures, discussion, and question \& answer. They were considered acceptable and effective in delivering the learning material. These results were in line with the study by Yarbrough (2018) which explained that indentifying, stating, and directing were the simplest learning method while the students' involvement in the learning process produced the development of new information and skills for them. This result was supported by the research of Nasution (2012) which stated that both conventional and unconventional methods have advantages and disanventages. For this reason, a teacher must be observant to look at the positive and negative aspect of those methods.

Fourth, the research result showed that the learning sources implemented by Nonformal Education Unit Sanggar Kegiatan Belajar Semarang were based on module which has been conducted in the learning planning process. According to Hadriyanto (2013), the implementation of the learning material should be regarded the conditions of the students themselves. When the students were not ready to learn, then the learning material might be delayed or modified to make it more interesting. Moreover, the learning material, especially package $C$, was ideally in accordance with the students' requirement.

Fifth, according to the research result, the learning assessment in Nonformal Education Unit Sanggar Kegiatan Belajar Semarang was based on the minimum comprehensiveness criteria and the attitude evaluation, while the implementation was carried out once in three weeks and in the final examination. Based on Suryana (2016) the learning assessment in Madani Package C program was carried out by using four types of assessments which included: (1) Daily assessment (2) Assessment of each module in the form of individual and group assessment, (3) Semester assessment, (4) Final evaluation which aimed to determine and decide the students in class rising.

Whereas, according to Yusuf (2014), the quality of the learning value was the academic achievement which was obtained by the students after they completed their study which was declared in the form of the learning scores or evaluation value. The learning evaluation value was seen as the ability of the students after they attended the learning activities.

\section{Package C Learning Implementation}

The delivering of learning material was the main of learning process. It was required some planned steps for delivering the material so that the learning process run effectively. Based on the research result, the learning activities steps which were carried out by the tutor in package $\mathrm{C}$ learning process included three main steps; they were preliminary activity, main activity, and closing activity. This result was relevant to the opinion by Rifa'i (2009: 123-125) that the steps of the learning process to the adult learners generally included preliminary, main, and closing activities. Then, it was supported by the research result of Ernawati (2017) which stated that there were three activities of the learning process stages, they were opening activity before the learning was carried out, main activity (material delivering), and closing activity (The activity to end the learning process).

First, the preliminary or opening activity was the integral part that could not be separated from othe stages. The research result by Sumiah (2013) stated that skills to open the the learning process could improve students' learning outcome because by attracting students's attention when the lessons starts will make them focus on the material given so that it will be easier to be mastered. In the other words, opening up the lessons was to prepare the 
students' mental and attention, so they focus on the things to be learned. This activity was an initial learning activity which aimed to condition the students to be ready in receiving the learning material. According to the research finding, the preliminary activity in package $\mathrm{C}$ learning included first activity by greetings. This was carried out in order to provide a warm and friendly atmosphere before the learning process began.

The second activity was praying together which aimed to get a successful learning process. The third activity that was carried out by the package $C$ tutor was asking how the students were. The fourth was checking the students' attendance; it was important to do because the tutor could know all the students and attracted their attention, so they devoted their attention in the learning process. The fifth activity was creating a condusive learning climate. It was influenced by the layout, learning facilities, and human relations (Rifa'i, 2009: 123). Based on the result of the study, the condusive learning climate, which was created in the package C learning, was the classroom must be far from the highway so there were no vehicle noises; there were a lot of trees around the building that made the cool atmosphere and fresh air. Afterwards, there was sentry group who cleaned the classroom, so the tidiness was maintained. The tables and chairs were neatly arranged to add the creation of the condusive learning climate.

This result was supported by the research result by Mohamed \& Schutte (2013) which stated that: "The study revealed that a learning climate can be created in different types of organizations through organizational, group and individual drivers. It further revealed that the strategy in creating a climate of learning should be aligned with the organization's structure, culture and goals". Even though, Fägerstam (2018) stated that the students' perception about the role of the learning environment in a broad sense have been explored by many ways, such as in relation on how the students' centered and teacher centered learning processes influenced the students' necessities and pshycological motivation. The sixth activity was that the tutor gave a reference. According to the result of this research, the tutor delivered the main material that would be learned because if it was not delivered so the goals of learning would not be achieved, and the learning process would not be effective

Second, the main activity was the presentation of the learning material. It used to learn model, learning strategy, learning media, and learning sources which were adapted with the students' characteristic and the lessons (Fauziah, 2017). The learning material presentation was one of the means to achieve the learning goals decided. In presenting the material, the tutor used lectured, questions\&answer, discussion, and practice learning methods. The use of them was adjusted with the students' necessities or the existed situation. Those research's results were supported by the theory of (Nurhalim, 2011: 83), that the common learning methods used in learning process included exercise, lectured, and question \& answer methods. Learning media was the supported means to create the effective learning situation (Nurseto, 2011). Learning media was an instrument used in the implementation of learning methods and technique. It was submitted to each tutor as he was more comprehensive to choose which media was acceptable to use in the learning process.

According to Triyanto (2013), learning process was a process of communication and occurred in a system, thus the learning media occupied the important position as one of the learning components. Package C learning media used included whiteboard, boardmarker, and module. Because of the technology limits in Nonformal Education Unit Sanggar Kegiatan Belajar Semarang made the tutors have not already use power point learning media, but it could be anticipated by using another media which supported the learning implementation. In the package $\mathrm{C}$ learning implementation, the tutors used the students centered learning. it could support the effective 
learning. This studies result was relevant to the theory by (Sanjaya, 2006: 30), that the principle which must be noticed in the learning activity management, concentrated in the students.

This finding was supported by the result study from (Antika, 2014), that the teachers were sure the learning would occur optimally if the students actively involved in the learning process. The tutors who distributed the knowledge acted to present the knowledge or information to the students. Therefore, they, in presenting the material, must be easily understood by the students, they realized that the students who attended the package $\mathrm{C}$ program had different abilities.by those differences, in the learning process; the tutors gave opportunity to the students for asking or presenting their opinion related to the material given. In addition, according to the result of this study, in the gap of the material presenatation the tutors also gave the motivatio to them. This was carried out to make the students seriously attend the learning process. In the result of the research by (Omar \& Noordin, 2013) stated that: "Motivation can be defined plainly as the process whereby goal-directed activity".

Motivation was very important in teaching learning activity, because it encouraged the learning spirit and conversaly; the lack of motivation would weaken the spirit of learning. Supported by the research result by (Waluyo \& Desmawati, 2015), which stated that motivation was the important factor in influencing the learning outcome.

Third, the closing activity was as important as the opening of learning. In order to end the lesson, there were three main activities that should be carried out (Rifa'i, 2009: 39), they were review, learning evaluation, and follow-up giving. According to the result of the study in package $\mathrm{C}$, the activity which was done by the tutors in the ending phase was reviewing the material given, it was done to make the students did not forget them. Afterwards, the tutors closed the learning activity by closing greetings. This result was supported by the research finding by (Paloloang, 2014), which stated that in closing activity, the implemented step was reviewing the material that have been presented by guiding the students for making a conclusion, the next step was ended the learning activity by greetings and praying together.

\section{Package C Learning Evaluation}

Brikerhoff (1986) in a journal (Maftuhatin, 2014) explained that evaluation is a process that determines the extent to which educational goals can be achieved. According to the Package $\mathrm{C}$ program evaluation focused on the learning process during the activity, it includes the ability of the tutor to deliver the material and the ability of learners to receive the learning materials (Hidayat, 2016). The results showed that the evaluation of learning was applied based on summative and formative evaluation where the implementation of summative evaluations was done as midterm test and formative evaluation was done at the end of the semester. The purpose of learning evaluation is to find out the achievement of the process and the learning objectives that have been set and to measure the extent to which people learn to understand the material that has been given. The follow up activity if learners have not yet met the minimum completeness criteria $(\mathrm{KKM})$ is that by conducting remedies or retest. However, the remedial exam is very rarely done because the assessment used is normative assesment where all students are able to meet the KKM. According to Ciptasari (2015) Program evaluation is not only done on knowledge aspects, but it is necessary to assess the behavior aspects that can be used to increase the professionalism of educators, improve the learning process and develop learners' attitude. The development of learners' behavior can be useful as a provision in the world of work that they are going to face in the future.

\section{CONCLUSION}

Conclusions in this research about Package C learning cover planning, learning and evaluation. The learning plan for the Package C Program includes: formulating learning objectives, preparing teaching 
materials, preparing teaching methods, choosing learning resources, and establishing assessment of learning outcomes.

The learning implementation on the Package $C$ program included three main stages.

main activity in Package $\mathrm{C}$ was materials presentation. The closing activities in Package $\mathrm{C}$ conducted by tutors included reviewing the material that had been delivered and closing the learning activities by greeting.

\section{REFERENCES}

Antika, R. R. (2014). Proses pembelajaran berbasis student centered learning (Studi deskriptif di sekolah menengah pertama Islam Baitul 'Izzah, Nganjuk). Jurnal biokultur, 3(1), 251-265.

Aritonang, K. T. (2008). Minat dan motivasi dalam meningkatkan hasil belajar siswa. Jurnal pendidikan penabur, 7(10), 11-21.

Auliya, F., \& Suminar, T. (2016). Strategi Pembelajaran yang Dapat Mengembangkan Kemandirian Belajar di Komunitas Belajar Qaryah Thayyibah. Journal of Nonformal Education and Community Empowerment, 5(1).

Bungin, M. B. Penelitian Kualitatif: Komunikasi, Ekonomi, Kebijakan Publik, dan Ilmu Sosial Lainnya. 2007. Jakarta: kencana.

Ciptasari, D. R., \& Utsman, U. (2015). Manajemen Program Pendidikan Kesetaraan Kejar Paket C "Harapan Bangsa" di UPTD SKB Ungaran Kabupaten Semarang. Journal of Nonformal Education and Community Empowerment, 4(2).

Ernawati, E., \& Mulyono, S. E. (2017). Manajemen Pembelajaran Program Paket C di Pkbm Bangkit Kota Semarang. Journal of Nonformal Education, 3(1), 60-71.

Fägerstam, E., \& Grothérus, A. (2018). Secondary School Students' Experience of Outdoor Learning: A Swedish Case Study. Education, 138(4), 378-392.

Fauziah, R., Abdullah, A. G., \& Hakim, D. L. (2017). Pembelajaran saintifik elektronika dasar berorientasi pembelajaran berbasis
They were the introduction, main, and closing. The preliminary activities carried out by tutors in Package $\mathrm{C}$ program were greeting, praying together, asking how the learners are, checking the learner's attendance, then the tutor delivered the main material to be studied. The

Learning evaluation was applied based on summative and formative evaluation. Where summative evaluation was carried out in the midterm test and formative evaluation was carried out at the end of the semester.

masalah. Innovation of Vocational Technology Education, 9(2).

Hadrianto, C. (2013). Penerapan Pendekatan Interaktif oleh Tutor dalam Pembelajaran Paket C Pada Kelompok Binuang Sakti Kota Padang. Spektrum: Jurnal Pendidikan Luar Sekolah (PLS), 1(2).

Hidayat, D. (2016). Pembelajaran partisipatif keterampilan berwirausaha untuk pemberdayaan ekonomi warga belajar kejar paket C. JPPM (Jurnal Pendidikan dan Pemberdayaan Masyarakat), 3(2), 122137.

(2016). Strategi Pembelajaran Partisipatif Dalam Meningkatkan Hasil Program Pendidikan Nonformal Di Kabupaten Karawang. Journal of Nonformal Education, 2(1).

Illeris, K. (2003). Towards a contemporary and comprehensive theory of learning. International journal of lifelong education, 22(4), 396-406.

Jogiyanto, H. M. (2007). Sistem informasi keperilakuan. Yogyakarta: Andi Offset.

Maftuhatin, L. (2014). Evaluasi Pembelajaran Anak Berkebutuhan Khusus (ABK) di Kelas Inklusif di SD Plus Darul'ulum Jombang. Religi: Jurnal Studi Islam, 5(2), 201-227.

Mohamed Hoosen Carrim, N., \& Schutte Basson, J. (2013). Creating a learning climate: a South African study. The Learning Organization, 20(1), 6-19.

Mustika, D. (2013). Proses Pembelajaran Kewirausahaan Pada Program Kejar Paket C "Harapan Bangsa" Di UPTD SKB (Sanggar Kegiatan Belajar) Ungaran Kabupaten Semarang. Journal of Nonformal Education and Community Empowerment, 2(1). 
Nasution, S. (2012). Metode Konvensional Dan Inkonvensional Dalam Pembelajaran Bahasa Arab. JURNAL ILMIAH DIDAKTIKA: Media Ilmiah Pendidikan dan Pengajaran, 12(2).

Nurhalim, K. (2011). Strategi Pembelajaran Pendidikan Non Formal. Semarang: Jurusan PLS FIP Unnes.

Nurseto, T. (2011). Membuat media pembelajaran yang menarik. Jurnal Ekonomi dan Pendidikan, 8(1).

Omar, S., Jain, J., \& Noordin, F. (2013). Motivation in learning and happiness among the low science achievers of a Polytechnic Institution: An exploratory study. Procedia-Social and Behavioral Sciences, 90, 702-711.

Rerung, N., Sinon, I. L., \& Widyaningsih, S. W. (2017). Penerapan model pembelajaran Problem Based Learning (PBL) untuk meningkatkan hasil belajar peserta didik SMA pada materi usaha dan energi. Jurnal Ilmiah Pendidikan Fisika AlBiruni, 6(1), 47-55.

Raharjo, T. J. (2005). Peran Seni Proses Pembelajaran Pendidikan Luar Sekolah (the Role of Art in the Learning Process in Out of School Educational). Harmonia: Journal of Arts Research and Education, 6(2).

Rifa'i, A. (2009). Desain Pembelajaran Orang Dewasa. Semarang: UNNES Press.

Rustaman, N. (2001). Ilmu dan Aplikasi Pendidikan. Bandung: PT. Imperial Bhakti Utama.

Sanjaya, W. (2006). Strategi Pembelajaran Berorientasi Standar Proses Pendidikan. Jakarta: Kencana Prenada Media Group. 2011. Penelitian Tindakan Kelas.

Saputra, W. A. (2015). Pembelajaran Kejar Paket $C$ yang Terintegrasi Lifeskill di UPTD SKB Ungaran (Doctoral dissertation, Universitas Negeri Semarang).

Shofwan, I., \& Kuntoro, S. A. (2014). Pengelolaan Program Pembelajaran Pendidikan alternatif Komunitas Belajar Qaryah Thayyibah di Salatiga Jawa Tengah. JPPM (Jurnal Pendidikan dan Pemberdayaan Masyarakat), 1(1), 50-62.

Slameto. (2003). Belajar dan Faktor-faktor yang Mempengaruhi. Jakarta: Rineka Cipta.

Suhaenah, E. (2016). Implikasi pendidikan kesetaraan paket $C$ terhadap peningkatan taraf hidup warga belajar di SKB kota Serang. Jurnal eksistensi pendidikan luar sekolah (e-plus), 1(1).
Sumiah, N., \& Khosmas, F. Y. (2013). Analisis keterampilan mengajar guru dalam meningkatkan hasil belajar pada mata pelajaran ekonomi di SMA. Jurnal Pendidikan dan Pembelajaran, 2(9).

Sungsri, S. (2018). Building the capability of nonformal education teachers to develop a learning society for promoting lifelong education in Thailand. International Journal of Educational Administration and Policy Studies, 10(2), 10-16.

Suryana, S. (2016). Model Pembelajaran dan Evaluasi Program Pendidikan Kesetaraan Paket B dan Paket C di Kota Semarang. Edukasi, 1(1).

Sutarto, J. (2017, January). Determinant Factors of The Effectiveness Learning Process and Learning Output of Equivalent Education. In 3rd NFE Conference on Lifelong Learning (NFE 2016). Atlantis Press.

Syahid, A. (2017). Teknik Identifikasi Program Paket C dalam Meningkatkan Keterampilan Fungsional Warga Belajar. Journal of Nonformal Education and Community Empowerment, 1(1), 18-25.

Triyanto, E., Anitah, S., \& Suryani, N. (2013). Peran kepemimpinan kepala sekolah dalam pemanfaatan media pembelajaran sebagai upaya peningkatan kualitas proses pembelajaran. Teknologi Pendidikan, 1(2), 226-238.

Vezne, R., Gunbayi, I., \& Hromatko, I. (2018). The Effect of Nonformal Learning on The Disabled People and Educators: a Case Study. European Journal of Education Studies.

Waluyo, Y. T., \& Desmawati, L. (2015). Peran Tutor Dalam Meningkatkan Motivasi Belajar Peserta Didik Melalui Pendekatan Andragogi di Rutan Banjarnegara. Journal of Nonformal Education and Community Empowerment, 4(1).

Widodo, H. (2016). Potret Pendidikan di Indonesia dan Kesiapannya dalam Menghadapi Masyarakat Ekonomi Asia (MEA). Cendekia: Jurnal Kependidikan Dan Kemasyarakatan, 13(2), 293-308.

Yarbrough, J. R. (2018). Adapting Adult Learning Theory to Support Innovative, Advanced, Online Learning--WVMD Model. Research in Higher Education Journal, 35. 
Muhammad Anis Sufyan, Imam Shofwan, Komsun Nurhalim / Journal of Nonformal Education 5 (1) (2019): 57-66 